\title{
Original Research Article \\ Research on Talent Training Mode of Vocational Education under the Background of Industry Education Integration
}

\author{
Wenbo Sun \\ School of Finance, Jilin Business and Technology College, Changchun, Jilin Province, China
}

\begin{abstract}
In the guiding ideology, basic ideas and main tasks of the transformation of colleges and universities, the guiding opinions on guiding the transformation of some local ordinary undergraduate colleges and universities to application-oriented have pointed out that "deepening the integration of production and education, establishing the talent training mode of integration of production and education and collaborative education, and promoting vocational education to really transfer the idea of running a school to the integration of industry and education and school enterprise cooperation".
\end{abstract}

Keywords: Vocational Education; Talent training Mode; Industry Education Integration

\section{The current talent training mode of integration of production and education}

Many experts and scholars have made in-depth research on the mode of industry education integration in vocational education

\subsection{Order form}

Order based talent training mode is a complete process of teaching, practice, training and so on, which is based on the pattern and specification of talent demand of enterprises and industries as well as the demand for job skills through signing a joint training mode with colleges and universities. Enterprises enter the school and teachers enter the classroom to jointly complete the teaching, practice, training and other complete process. At first, most vocational colleges began to integrate production and education in such a mode, such as "securities company order class" of J college, "bank order class" of J University, and "m route order class" of W shipbuilding college. Here, the school will jointly cultivate talents according to the needs of enterprises or industries, carry out the education and management of students according to the needs of enterprises or industries, regularly carry out lectures, awards, assessment or elimination, and finally select excellent talents.

\section{2 "2 + 1" formula}

" $2+1$ " mode is to divide the whole educational system into two stages. The first two years of general education, professional basic courses and basic professional practice training are completed in the school, while the professional training and post practice with high professional or technical requirements are completed in the enterprise in the last year of the school system. The advantage of this is that students can be very familiar with the work content before they enter the formal job. During the school period, they can closely combine the theoretical knowledge with the practice, making the knowledge more flexible, and saving the cost of induction training for enterprises. For example, in the third line construction period, some machinery, electrical machinery and other industrial enterprises will choose to carry out this " $2+1$ ” talent training mode in vocational colleges.

\section{3 "Work study alternation"}

The mode of "work study alternation" refers to the talent training plan jointly formulated by schools and enterprises, which clearly reflects that students' theoretical study and enterprise practice are alternately carried out, similar to the form of part-time work and part-time study. Under such a mode, students can get certain remuneration during the internship period of the enterprise. At the same time, the enterprise can also inspect the whole process of students' learning system. Then, students can choose whether to continue to engage in this industry according to the learning content. In this talent cultivation mode, students' professional quality and comprehensive quality can be improved.

\section{Existing problems}

\subsection{The curriculum is not targeted}

According to the existing research on the talent training mode of integration of production and education, although vocational 
colleges have identified the talent demand of enterprises from the survey of talent demand in the market, and also made timely adjustments, such adjustment may make the specialty itself lack of characteristics, which will inhibit the future development of vocational colleges. But for vocational colleges, there are also difficulties in curriculum setting. After the courses with talent demand can be determined, the update speed of course content is far behind the change speed of enterprise's demand for talents and posts for employment. We have a cyclical approach to the training of talents, and the adjustment of talent training programs in Colleges and universities is also cyclical. It is necessary to complete at least one academic year before curriculum adjustment can be carried out.

\subsection{The specialty settings are repeated}

The repetition of specialty setting has always been a pain in vocational colleges. First of all, in the current vocational colleges production and education integration talent training program formulation process, the enterprise participation is not enough, the main reason is the government's guidance in the cooperation of insufficient intervention. For enterprises, it will put forward the current employment standards and requirements at the initial stage of specialty setting, and put forward opinions on the formulation of specialty setting and talent training plan, and participate in the revision. However, with the development of the school system, the needs of the industry or occupation will change at any time. The participation of enterprises in the process of personnel training is not enough, resulting in the students trained by the school cannot be directly qualified for specific jobs without pre job training.

\subsection{The teaching method is too traditional}

Most teachers are familiar with the traditional teaching mode, because in the traditional classroom teaching, teachers are "teaching centered", with stronger initiative and more obvious advantages. With the rapid penetration of information technology, especially the widespread popularity of MOOC in Higher Education in recent years, how to get rid of the shackles of traditional education and teaching mode, with the help of the vigorous development of vocational education informatization, to realize the reform of teaching mode has become a key link to improve the quality of personnel training.

\section{Solutions}

\subsection{Strengthen the construction of power mechanism between schools and enterprises}

To make clear the driving mechanism of the enterprise and whether it can activate the power of the enterprise to participate in the integration of industry and education, we should "throw in what it likes" to maximize the profit of the enterprise and let the enterprise be willing to participate in it.First of all, to enhance the status of enterprises in the integration of production and education, enterprises should also fully share the right of management, supervision and evaluation in the integration of production and education, so as to change the dominant position of colleges and universities in personnel training, and help to form a benign mechanism of school enterprise collaborative education. Secondly, we should establish the system of giving priority to the selection of talents. The purpose of enterprise participation in education is to enrich its own human resources, with the help of its rich economic benefits, promote the rapid development of enterprises. Finally, in order to protect the legitimate interests of enterprises, we should, on the basis of adhering to the principle of "mutual benefit", distribute the income of both the University and the enterprise according to their work, investment proportion and performance, and constantly adjust according to the cooperation process to form a benefit distribution scheme in line with the actual situation. In this way, the interests of both sides of the University and the enterprise are effectively protected.

\subsection{Deepen the connotation construction of education}

Firstly, on the basis of local industrial structure, local pillar industries and local planning policies, vocational colleges should highlight local characteristics and formulate professional development plans scientifically. Secondly, when setting up a major, we should give full play to the role of the professional Steering Committee, give full play to the role of enterprise representatives and industry organization representatives in the committee, strengthen professional research, such as through local government departments to understand the development of local industries; in-depth visits to enterprises to grasp the status quo and employment needs of enterprises; widely carry out exchanges with brother colleges to avoid professional design Set repetition, realize dislocation development. Finally, based on the regional industrial structure, enterprise job demand, graduates' employment quality report and so on, the specialty is set up, so that the specialty is really built on the industrial chain.

\subsection{Increase economic support for school enterprise cooperation}

The integration of industry and education needs funds as support, and government finance is the main source. Therefore, local colleges and universities should be set up in accordance with the proportion of government finance and industry to support the healthy development of teaching and education.

\section{Acknowledgements}

Based on Jilin occupation education and adult education reform research topics: Research on the dynamic mechanism of occupation poverty alleviation in Jilin province with new apprenticeship as the path (2019ZCY331).

\section{References}

1 Jing Lili. Private enterprise undergraduate school enterprise cooperation, production and teaching integration personnel training mode to explore [J]. Think Tank Era, 2017 (01).

$2 \mathrm{Xu}$ Meiling, Wang Yunli. Research on the innovation of compound talents training mode from the perspective of "school enterprise cooperation and industry education integration" [J]. Modern Economic Information, 2019 (10). 